medRxiv preprint doi: https://doi.org/10.1101/2022.03.01.22271717; this version posted March 2, 2022. The copyright holder for this preprint (which was not certified by peer review) is the author/funder, who has granted medRxiv a license to display the preprint in perpetuity. It is made available under a CC-BY-NC-ND 4.0 International license .

\title{
Prevalence of Chronic Diseases, Depression, and Stress among U.S. Child Care Professionals during the COVID-19 Pandemic
}

Jad A. Elharake, MPH a,b; Mehr Shafiq, MPH', ; Ayse Cobanoglu, PhD ${ }^{\text {d }}$; Amyn A. Malik, MBBS, MPH, PhD ${ }^{\mathrm{a}, \mathrm{b}}$; Madeline Klotz, BA ${ }^{\mathrm{e}}$; John Eric Humphries, PhD; ; Thomas Murray, MD, PhD"g; Kavin M. Patel, MDª David Wilkinson, JD ${ }^{\mathrm{f}, \mathrm{h}}$; Inci Yildirim, MD, PhD, MSc ${ }^{\mathrm{b}, \mathrm{g}, \mathrm{h}}$; Rachel Diaz, BA ${ }^{\text {h}}$; Rosalia Rojas, BA ${ }^{\text {d; }}$ Anael Kuperwajs Cohen, BA ${ }^{\text {d; }}$ Aiden Leef Chin R. Reyes, PhD ${ }^{\mathrm{d}}$; Saad B. Omer, MBBS, MPH, PhD ${ }^{\mathrm{a}, \mathrm{b}, \mathrm{j}, \mathrm{k}}$; Walter S. Gilliam, PhD ${ }^{\mathrm{d}}$

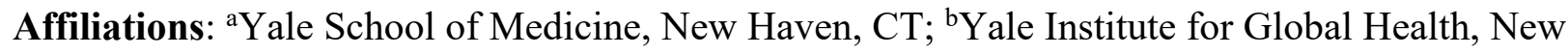
Haven, CT; ' Mailman School of Public Health, Columbia University, New York, NY; ${ }^{\text {d} Y a l e ~}$ Child Study Center, Yale School of Medicine, New Haven, CT; ${ }^{e}$ Human Development and Family Studies, Michigan State University, East Lansing, Michigan; fDepartment of Economics, Yale University, New Haven, CT; 'Department of Pediatrics, Yale School of Medicine, New Haven, CT; ${ }^{h}$ Tobin Center for Economic Policy, Yale University, New Haven, CT; ${ }^{\text {hDepartment }}$ of Epidemiology of Microbial Diseases, Yale School of Public Health, New Haven, CT; ${ }^{\text {YY }}$ ale School of Public Health, New Haven, CT; ${ }^{k}$ Yale School of Nursing, New Haven, CT

Corresponding Author: Jad A. Elharake, MPH, Yale Institute for Global Health, 1 Church Street, New Haven, CT 06510. Email: jad.elharake@yale.edu, Phone Number: 313-443-5150

Short Title: Physical and Mental Health of U.S. Child Care Professionals 
medRxiv preprint doi: https://doi.org/10.1101/2022.03.01.22271717; this version posted March 2, 2022. The copyright holder for this preprint (which was not certified by peer review) is the author/funder, who has granted medRxiv a license to display the preprint in perpetuity. It is made available under a CC-BY-NC-ND 4.0 International license.

Conflict of Interest Disclosures: All authors report no conflicts of interest.

Funding: All phases of this study were supported by the Andrew \& Julie Klingenstein Family

Fund, Esther A. \& Joseph Klingenstein Fund, Heising-Simons Foundation, W.K. Kellogg

Foundation, Foundation for Child Development, Early Educator Investment Collaborative, and

Scholastic Inc. The funders/sponsors did not participate in the work.

Manuscript word count: 2,968 
medRxiv preprint doi: https://doi.org/10.1101/2022.03.01.22271717; this version posted March 2, 2022. The copyright holder for this preprint (which was not certified by peer review) is the author/funder, who has granted medRxiv a license to display the preprint in perpetuity. It is made available under a CC-BY-NC-ND 4.0 International license.

\section{Key Points}

Question: What is the prevalence of chronic diseases, depression, and stress among U.S. child care professionals during the COVID-19 pandemic?

Findings: In this survey of 81,682 U.S. child care professionals, $14.3 \%$ reported moderate to severe asthma, $6.5 \%$ diabetes, $4.9 \%$ heart disease, $19.8 \%$ being obese, $45.7 \%$ screening positive for depression, and $66.5 \%$ moderate to high stress levels.

Meaning: During the pandemic, child care professionals reported depression rates much higher than before the pandemic, and asthma, stress, and depression much greater than U.S. adult estimates, highlighting a need for effective supports for the wellbeing of this essential workforce. 
medRxiv preprint doi: https://doi.org/10.1101/2022.03.01.22271717; this version posted March 2, 2022. The copyright holder for this preprint (which was not certified by peer review) is the author/funder, who has granted medRxiv a license to display the preprint in perpetuity.

\begin{abstract}
Importance: There is no published national research reporting child care professionals' physical health, depression, or stress during the COVID-19 pandemic. Given their central role in supporting children's development, child care professionals' overall physical and mental health is important.
\end{abstract}

Objectives: To evaluate the prevalence of chronic diseases, depression, and stress levels during the COVID-19 pandemic among U.S. child care professionals.

Design: In this large-scale national survey, data were collected through an online survey from May 22, 2020 to June 8, 2020. We analyzed the association of sociodemographic characteristics with four physical health conditions (asthma, heart disease, diabetes, and obesity), depression, and stress weighted to national representativeness. Sociodemographic characteristics included race, ethnicity, age, gender, medical insurance status, and child care type.

Setting: Center- and home-based child care.

Participants: Child care professionals $(\mathrm{n}=81,682)$ from all U.S. states and the District of Columbia.

Results: Mean age was 42.1 years (standard deviation $=14.1) ; 96.0 \%(\mathrm{n}=78,725)$ were female, $2.5 \%(n=2,033)$ were male, and $0.3 \%(n=225)$ were non-binary. For physical health conditions, $14.3 \%(n=11,717)$ reported moderate to severe asthma, $6.5 \%(n=5,317)$ diabetes, $4.9 \%(n=3,971)$ heart disease, and 19.8\% $(n=16,207)$ being obese. Regarding mental health, $45.7 \%(\mathrm{n}=37,376)$ screened positive for depression and $66.5 \%(\mathrm{n}=54,381)$ reported moderate to high stress levels. Race, ethnicity, and gender disparities were evidenced for physical health conditions of child care professionals, but not for mental health during the pandemic. 
medRxiv preprint doi: https://doi.org/10.1101/2022.03.01.22271717; this version posted March 2, 2022. The copyright holder for this preprint (which was not certified by peer review) is the author/funder, who has granted medRxiv a license to display the preprint in perpetuity. It is made available under a CC-BY-NC-ND 4.0 International license.

Conclusions and Relevance: Our findings highlight that child care professionals' depression rates during the pandemic were much higher than before the pandemic, and depression, stress and asthma rates were higher than U.S. adult depression rates during the pandemic. Given the essential work child care professionals provide during the pandemic, policy makers and public health officials should consider what can be done to support the physical and mental health of child care professionals. 
medRxiv preprint doi: https://doi.org/10.1101/2022.03.01.22271717; this version posted March 2, 2022. The copyright holder for this preprint (which was not certified by peer review) is the author/funder, who has granted medRxiv a license to display the preprint in perpetuity.

\section{Introduction}

There are approximately 1.1 million paid and registered child care professionals in the United States (U.S.) providing care for 10 million children across center- and home-based settings. ${ }^{1,2}$ While child care professionals play a central role in children's learning and personal development, they represent a highly vulnerable workforce, ${ }^{3}$ consisting largely of women and in many child care sectors racial and ethnic minorities, immigrants, and lower-income individuals. ${ }^{4}$ As an historically exploited labor group, ${ }^{5}$ child care is one of the lowest-paid occupations in the U.S., with an annual salary $67 \%$ below the national average. ${ }^{3}$ Child care professionals face challenging work conditions including long hours and high job demands, ${ }^{6-9}$ leading to staff turnover, absenteeism, poor physical health conditions, high rates of burnout, emotional exhaustion, and mental health. ${ }^{10}$

The unpredictable nature and impact of the coronavirus disease-2019 (COVID-19) pandemic has further exacerbated the financial and work-related stress faced by child care professionals. ${ }^{11,12}$ Despite extensive mitigation strategies to contain the pandemic, many child care programs closed in March 2020. ${ }^{13}$ Unlike many schools and universities that fully transitioned to online learning, there were no alternative virtual platforms for a majority of child care programs. ${ }^{13}$ As a result, more than $35 \%$ of jobs in the child care industry were lost. ${ }^{14}$ Not only did this threaten the financial stability of child care professionals and families that rely on child care for their employability, ${ }^{1,15,16}$ it also limited children's educational, social, and nutritional opportunities ${ }^{17}$ and may have further worsened the physical and mental health of child care professionals. ${ }^{11,12}$

There is no published national research reporting child care professionals' physical health, depression, or stress during the COVID-19 pandemic. Pre-pandemic studies on child care 
medRxiv preprint doi: https://doi.org/10.1101/2022.03.01.22271717; this version posted March 2, 2022. The copyright holder for this preprint (which was not certified by peer review) is the author/funder, who has granted medRxiv a license to display the preprint in perpetuity. It is made available under a CC-BY-NC-ND 4.0 International license .

professionals have reported a $7.3 \%$ rate of diabetes, ${ }^{18}$ obesity rates ranging from $34 \%$ to $66.3 \%,{ }^{18-21}$ and clinical depression rates ranging from $16.0 \%$ to $36.1 \% .^{21-25}$ These rates compare to the overall rates for U.S. adult women of $8.7 \%$ for diabetes, ${ }^{26} 41.9 \%$ for obesity, ${ }^{27} 9.6 \%$ for depression pre-pandemic, ${ }^{28}$ and $27.8 \%$ to $32.8 \%$ for depression during the pandemic. ${ }^{29-31}$ There is only one study focusing on the stress levels of child care professionals during the pandemic, conducted in Indiana, which found that $63 \%$ of child care professionals reported moderate to high stress levels, ${ }^{12}$ almost twice the national estimate of $37 \%$ for U.S. adults during the pandemic. ${ }^{32}$ Prior to the pandemic, $36.8 \%$ to $62.1 \%$ of child care professionals were reported to be experiencing moderate to high levels of stress. ${ }^{12,20,33}$

Given that the well-being of child care professionals is associated with children's academic and emotional learning outcomes, ${ }^{9,25,33,34}$ it is imperative to understand and address the condition of child care professionals during the pandemic and beyond. While relatively small-scale studies have documented the mental health status of early childhood educators prior to the COVID-19 pandemic, ${ }^{9,18-21,24,25,33,35-37}$ very little is known about their physical and mental health status during the pandemic. This study evaluates the prevalence of chronic diseases, depression, and stress levels during the COVID-19 pandemic among U.S. child care professionals.

\section{Methods}

\section{$\underline{\text { Study Design and Participants }}$}

Data were collected from self-identifying child care professionals through an online Qualtrics ${ }^{\circledR}$ survey distributed from May 22, 2020 to June 8, 2020, about 10 to 13 weeks into the COVID-19 pandemic, through various contact lists of individuals associated with the child care industry, as 
medRxiv preprint doi: https://doi.org/10.1101/2022.03.01.22271717; this version posted March 2, 2022. The copyright holder for this preprint (which was not certified by peer review) is the author/funder, who has granted medRxiv a license to display the preprint in perpetuity. It is made available under a CC-BY-NC-ND 4.0 International license.

described previously. ${ }^{38}$ Inclusion criteria were participants who self-identified as child care professionals working in child care before or during the pandemic; consented to the study; were 18 years or older; and resided in a U.S. state or the District of Columbia. Of the 94,390 individuals who accessed the survey, 82,613 satisfied inclusion criteria and 81,682 (98.9\%) provided data necessary for analyses. Participants were offered entry into a raffle for one of 20 $\$ 500$ gift cards. The research protocol was approved by the Yale University Institutional Review Board as a Category 2(ii) exempt protocol (\#2000028232).

\section{Variables}

\section{Chronic Diseases and Health Conditions}

Ten chronic diseases and physical health conditions, identified as risk factors for COVID-19 complications by the Centers for Disease Control and Prevention (CDC) at the time of the survey ${ }^{39}$ were asked in the survey with respondents indicating which apply to them: chronic lung disease/chronic obstructive pulmonary disease (COPD), chronic/severe kidney disease, liver disease, heart disease, immune-compromising conditions (such as immune deficiencies bone marrow/organ transplant), immunosuppressive treatments for cancer or an inflammatory disease (such as lupus, rheumatoid arthritis, etc.), smoking, diabetes, asthma (moderate to severe), and obesity. Asthma, diabetes, heart disease, and obesity had the highest prevalence in our sample and were therefore selected for further analysis. Prevalence of the remaining six physical health conditions were analyzed by sociodemographic characteristics. 
medRxiv preprint doi: https://doi.org/10.1101/2022.03.01.22271717; this version posted March 2, 2022. The copyright holder for this preprint (which was not certified by peer review) is the author/funder, who has granted medRxiv a license to display the preprint in perpetuity.

Depressive Symptoms

The 10-item Center for Epidemiological Studies-Depression (CES-D-10) scale is a reliable and valid self-report scale designed to measure depressive symptomatology and screen for Major Depression. ${ }^{40}$ Items assess depression-related symptoms experienced in the past week $(0=$ Rarely or none of the time; $1=$ Some or little of the time; $2=$ Occasionally or a moderate amount of the time; $3=$ All of the time), such as restless sleep, poor appetite, and feelings of loneliness, with positively stated items reverse coded prior to calculating sum scores. As in other studies, ${ }^{30,41,42}$ sum scores greater than or equal to 10 were considered positive for depression.

Stress

The 10-item Perceived Stress Scale (PSS-10) is a validated short-form version of the Perceived Stress Scale, the most widely used psychological instrument for measuring the perception of stress. ${ }^{43}$ Questions ask about feelings and thoughts during the last month and are rated on a fivepoint Likert Scale $(0=$ Never; $1=$ Almost Never; $2=$ Sometimes; $3=$ Fairly Often; $4=$ Very Often). ${ }^{44}$ Positively stated items were reverse coded. Sum scores ranging from 0-13 are considered low stress, 14-26 are moderate stress, and 27-40 are high stress. ${ }^{45}$

\section{Sociodemographic Factors}

Respondents were asked to provide information on their racial and ethnic backgrounds with items worded identically to the most recent U.S. Census questionnaire. Options for race included White, Black/African American, American Indian/Alaska Native, Native Hawaiian/Pacific Islander, and Asian, and respondents who selected more than one race were coded as 
medRxiv preprint doi: https://doi.org/10.1101/2022.03.01.22271717; this version posted March 2, 2022. The copyright holder for this preprint (which was not certified by peer review) is the author/funder, who has granted medRxiv a license to display the preprint in perpetuity. It is made available under a CC-BY-NC-ND 4.0 International license.

'multiracial.' Additionally, ethnicity (Hispanic, Latino, or Spanish Origin versus not), access to medical insurance, gender, age, and child care program type were considered in the analysis.

Data Weighting and Missing Data Analysis and Treatment

The sample was weighted to national representativeness for U.S. child care professionals by state, age, race, and ethnicity based on the 2019 American Community Survey, ${ }^{46}$ with the top and bottom $5 \%$ of the weights trimmed to reduce sampling variance. Missing data analysis and multiple imputation of missing data are described in eMethods.

\section{$\underline{\text { Statistical Analysis }}$}

Descriptive statistics were used to present all variables. Separate multivariable logistic regression models were used to assess the association of covariates (age, race, ethnicity, gender, program type, and medical insurance) with prevalence of heart disease, asthma, diabetes, and obesity, individually. Separate multivariable linear regression models were used to assess the association of these covariates with self-reported depression and stress scores. Significance was set to alpha $=0.05$, two-tailed. Analyses were conducted in SPSS Statistics (version 28.0.1.) and R (version R.4.1.1.).

\section{Results}

\section{Demographics Characteristics}

Of the total sample $(n=81,682)$, the mean age was 42.1 years $($ standard deviation $[$ std $]=14.1)$. Across racial categories, $63.8 \%(\mathrm{n}=52,164)$ were White, $14.5 \%(\mathrm{n}=11,837)$ Black/African American, 3.6\% $(\mathrm{n}=2$,949) Asian, 3.6\% $(\mathrm{n}=2,944)$ multiracial, 1.9\% $(\mathrm{n}=1,582)$ American 
medRxiv preprint doi: https://doi.org/10.1101/2022.03.01.22271717; this version posted March 2, 2022. The copyright holder for this preprint (which was not certified by peer review) is the author/funder, who has granted medRxiv a license to display the preprint in perpetuity. It is made available under a CC-BY-NC-ND 4.0 International license .

Indian/Alaska Native, $0.6 \%(n=491)$ Native Hawaiian/Pacific Islander, and $11.9 \%(n=9,731)$ preferred not to identify their race. Across the ethnic category, $21.7 \%(\mathrm{n}=17,753)$ identified as Hispanic. Also, $96.4 \%(n=78,725)$ of the sample identified as female, $2.5 \%(n=2,033)$ as male, and $0.3 \%(n=225)$ as non-binary. Most respondents worked in child care centers, with $24.5 \%(n$ $=19,976)$ in for-profit centers. Lastly, $89.2 \%(\mathrm{n}=72,890)$ of the sample reported access to medical insurance (Table 1).

Chronic Diseases and Physical Health Conditions

Of the 10 chronic diseases and physical health conditions considered, the greatest rates were found for asthma $(14.3 \% ; n=11,717)$, diabetes $(6.5 \% ; n=5,317)$, heart disease $(4.9 \% ; 3,971)$, and obesity $(19.8 \% ; \mathrm{n}=16,207)$. Prevalence for each across sociodemographic characteristics can be found in Table 1. Significant sociodemographic predictors for each are presented below and full results are presented in Table 2.

\section{Asthma}

Compared to White child care professionals, American Indian/Alaska Native (Odds ratio [OR] = 1.44; 95\% Confidence Interval $[\mathrm{CI}]=1.23-1.69)$, Black/African American $(\mathrm{OR}=1.09 ; 95 \% \mathrm{CI}$ $=1.02-1.16)$, and multiracial $(\mathrm{OR}=1.62 ; 95 \% \mathrm{CI}=1.47-1.79)$ child care professionals had higher odds of having asthma, while controlling for other covariates, whereas Asian $(\mathrm{OR}=0.74$; 95\% CI $=0.64-0.84)$ participants had lower odds of having asthma. Participants who identified as Hispanic had lower odds $(\mathrm{OR}=0.90 ; 95 \% \mathrm{CI}=0.85-0.96)$ of having asthma than those who did not, while controlling for other covariates. Compared to females, participants who identified as non-binary had higher odds of asthma $(\mathrm{OR}=1.58 ; 95 \% \mathrm{CI}=1.11-2.25)$. Those who did not 
medRxiv preprint doi: https://doi.org/10.1101/2022.03.01.22271717; this version posted March 2, 2022. The copyright holder for this preprint (which was not certified by peer review) is the author/funder, who has granted medRxiv a license to display the preprint in perpetuity. It is made available under a CC-BY-NC-ND 4.0 International license.

have medical insurance had lower odds of having asthma $(\mathrm{OR}=0.74 ; 95 \% \mathrm{CI}=0.68-0.80)$ than those who did have medical insurance, while controlling for other covariates.

\section{Diabetes}

Compared to White child care professionals, American Indian/Alaska Native (OR = 2.34; 95\% $\mathrm{CI}=1.96-2.80)$, Asian $(\mathrm{OR}=1.34 ; 95 \% \mathrm{CI}=1.11-1.62)$, Black/African American $(\mathrm{OR}=1.86$; 95\% CI $=1.71-2.03)$, and Native Hawaiian/Pacific Islander $(\mathrm{OR}=1.88 ; 95 \% \mathrm{CI}=1.34-2.64)$ child care professionals had higher odds of having diabetes, while controlling for other covariates. Participants who identified as Hispanic had higher odds $(\mathrm{OR}=1.34 ; 95 \% \mathrm{CI}=1.22$ 1.47) of having diabetes than those who did not, while controlling for other covariates. Those who did not have medical insurance had lower odds of having diabetes $(\mathrm{OR}=0.81 ; 95 \% \mathrm{CI}=$ 0.72-0.92) than those who did have medical insurance, while controlling for other covariates.

\section{Heart Disease}

Compared to White child care professionals, American Indian/Alaska Native (OR $=1.42 ; 95 \%$ $\mathrm{CI}=1.11-1.82)$, Black/African American $(\mathrm{OR}=1.14 ; 95 \% \mathrm{CI}=1.03-1.26)$, and multiracial $(\mathrm{OR}$ $=1.74 ; 95 \% \mathrm{CI}=1.46-2.08)$ child care professionals had higher odds of having heart disease, while controlling for ethnicity, gender, age, insurance status, and program type. Males (OR = $1.49 ; 95 \% \mathrm{CI}=1.22-1.80)$ and non-binary participants $(\mathrm{OR}=1.97 ; 95 \% \mathrm{CI}=1.01-3.84)$ had higher odds of having heart disease than did females. 
medRxiv preprint doi: https://doi.org/10.1101/2022.03.01.22271717; this version posted March 2, 2022. The copyright holder for this preprint (which was not certified by peer review) is the author/funder, who has granted medRxiv a license to display the preprint in perpetuity. It is made available under a CC-BY-NC-ND 4.0 International license.

\section{Obesity}

Compared to White child care professionals, multiracial $(\mathrm{OR}=1.30 ; 95 \% \mathrm{CI}=1.18-1.43)$ child care professionals had higher odds of having obesity, while controlling for other covariates, whereas Asian $(\mathrm{OR}=0.27 ; 95 \% \mathrm{CI}=0.22-0.31)$ and Native Hawaiian/Pacific Islander $(\mathrm{OR}=$ $0.76 ; 95 \% \mathrm{CI}=0.58-0.99)$ participants had lower odds of having obesity. Participants who identified as Hispanic had lower odds $(\mathrm{OR}=0.75 ; 95 \% \mathrm{CI}=0.71-0.80)$ of having obesity than those who did not, while controlling for other covariates. Those who did not have medical insurance had lower odds of having obesity $(\mathrm{OR}=0.94 ; 95 \% \mathrm{CI}=0.88-1.00)$ than those who had medical insurance, while controlling for other covariates.

\section{Other Physical Health Conditions}

Prevalence of the remaining six chronic diseases and physical health conditions were $4.4 \%(\mathrm{n}=$ 3,619) for smoking, $4.7 \%(\mathrm{n}=3,851)$ for immune weakening medications, $2.3 \%(\mathrm{n}=1,884)$ for immune compromising conditions, $1.0 \%(\mathrm{n}=814)$ for chronic lung disease/COPD, $0.7 \%(\mathrm{n}=$ 562) for chronic/severe kidney disease, and $0.7 \%(n=545)$ for liver disease. Rates by sociodemographic characteristics are in eTable 1. Overall, $26.2 \%(n=21,398)$ of respondents reported at least one medically compromising condition, $9.7 \%(\mathrm{n}=7,962)$ reported two, and $4.0 \%(n=3,239)$ reported three or more, as shown in eTable 2. 
medRxiv preprint doi: https://doi.org/10.1101/2022.03.01.22271717; this version posted March 2, 2022. The copyright holder for this preprint (which was not certified by peer review) is the author/funder, who has granted medRxiv a license to display the preprint in perpetuity. It is made available under a CC-BY-NC-ND 4.0 International license.

\section{$\underline{\text { Mental Health }}$}

Depressive Symptoms

Of the total sample, $45.7 \%(n=37,376)$ of child care professionals screened positive for depression $($ CES-D-10 $\geq 10)$, with a mean score of $10.2(\mathrm{std}=6.0)$. The prevalence of clinically relevant depressive symptoms and mean CES-D-10 scores across sociodemographic characteristics can be found in Table 3. For every one-year increase in age, on average, the CESD-10 sum score decreased $(\beta=-0.11 ; 95 \% \mathrm{CI}=-0.16$ to -0.05$)$. Compared to participants who worked in for-profit centers, participants in home-based programs reported lower CES-D-10 sum scores $(\beta=-2.30 ; 95 \% \mathrm{CI}=-3.89$ to -0.72$)$, while controlling for other covariates (Table 4).

Stress

Of the total sample, $33.4 \%(n=27,317)$ of child care professionals reported low stress levels, $42.5 \%(n=34,752)$ reported moderate stress levels, and $24.0 \%(n=19,629)$ reported high stress levels, with a mean score of $17.5(\mathrm{std}=7.4)$. The prevalence of various stress levels and mean PSS-10 scores across sociodemographic characteristics can be found in Table 3. For every oneyear increase in age, on average, the PSS-10 sum score decreased $(\beta=-0.07 ; 95 \% \mathrm{CI}=-0.11$ to 0.03). Compared to participants who worked in for-profit centers, participants in home-based programs, reported lower PSS-10 sum scores $(\beta=-1.54 ; 95 \% \mathrm{CI}=-2.45$ to -0.63$)$, while controlling for other covariates (Table 4). 
medRxiv preprint doi: https://doi.org/10.1101/2022.03.01.22271717; this version posted March 2, 2022. The copyright holder for this preprint (which was not certified by peer review) is the author/funder, who has granted medRxiv a license to display the preprint in perpetuity. It is made available under a CC-BY-NC-ND 4.0 International license .

\section{Discussion}

In the largest national study of the physical and mental health of U.S. child care professionals, child care professionals during the COVID-19 pandemic reported a significantly higher depression rate compared to pre-pandemic estimates, and asthma and stress levels much greater than the U.S. adult estimates. Additionally, race, ethnicity, and gender disparities were evidenced for physical health conditions of child care professionals, but not for mental health during the pandemic. Our findings highlight a need for effective supports for the overall wellbeing of this vulnerable, yet essential, workforce.

The depression rate for child care professionals (45.7\%) two to three months into the COVID-19 pandemic was greater than estimates for child care professionals prior to the pandemic $(16.0 \%$ to $36.1 \%),{ }^{21-25}$ and notably greater than estimates for U.S. adults during the pandemic $(27.8 \%$ to $32.8 \%) .{ }^{29-31}$ In terms of stress levels, about two thirds $(66.5 \%)$ of child care professionals reported moderate $(42.5 \%)$ or high $(24.0 \%)$ stress levels, almost twice the estimate for U.S. adults during the pandemic. ${ }^{32}$ This rate of stress among child care professionals is greater than pre-pandemic rates for child care professionals, ${ }^{12,20,33}$ and similar to rates during the early months of the pandemic reported by others. ${ }^{12}$

Across 10 medical conditions identified by the CDC near the beginning of the pandemic as risk factors for COVID-19 complications, ${ }^{39} 26.2 \%$ reported one, $9.7 \%$ reported two, and $4.0 \%$ reported three or more. Asthma rates for child care professionals in this study $(14.3 \%)$ were about 1.2 times the national average for U.S. women. ${ }^{47}$ Asthma is associated with lowsocioeconomic status and is more prevalent in communities of color, with those living in lowincome neighborhoods at increased exposure to indoor allergens and airborne toxins often due to 
medRxiv preprint doi: https://doi.org/10.1101/2022.03.01.22271717; this version posted March 2, 2022. The copyright holder for this preprint (which was not certified by peer review) is the author/funder, who has granted medRxiv a license to display the preprint in perpetuity. It is made available under a CC-BY-NC-ND 4.0 International license .

inadequately ventilated housing. ${ }^{48-50}$ Additionally, child care centers are often poorly ventilated and have high levels of indoor air pollutants, ${ }^{51-54}$ suggesting the need for greater attention to air quality in child care facilities to protect the health of child care professionals and reduce their vulnerability to COVID-19 complications. ${ }^{55}$ In contrast to asthma, child care professionals' rates for diabetes $(6.5 \%)$, heart disease $(4.9 \%)$, and obesity $(19.8 \%)$ were below national rates for U.S. adult women. ${ }^{26,27,56}$

Race, ethnicity, and gender disparities were evidenced for physical health conditions of child care professionals, but not for mental health during the pandemic. Compared to White child care professionals, those who identified as either American Indian/Native Alaskan or Black/AfricanAmerican were at increased odds for asthma, heart disease, and diabetes, and multiracial child care professionals were at increased odds of asthma, heart disease, and obesity. Both findings are consistent with the racial and ethnic disparities among U.S. adult women. ${ }^{27,47,56}$ Illustrating these disparities, 7.4\% of American Indian/Native Alaskan child care professionals reported three or more chronic health conditions that place them at greater risk of COVID-19 complications, compared to $4.0 \%$ for child care professionals overall. Of the physical health conditions examined, diabetes showed the greatest level of disparities, with all racial groups (except multiracial) and Hispanic showing increased odds when compared to White child care professionals, which is consistent with the racial and ethnic disparities among U.S. adult women. ${ }^{57}$ Also, child care professionals who reported non-binary gender identity were at increased odds of both asthma and heart disease.

In terms of child care setting, professionals working in the federally-funded Head Start or Early Head Start program were at greater odds for diabetes and obesity, compared to professionals 
medRxiv preprint doi: https://doi.org/10.1101/2022.03.01.22271717; this version posted March 2, 2022. The copyright holder for this preprint (which was not certified by peer review) is the author/funder, who has granted medRxiv a license to display the preprint in perpetuity. It is made available under a CC-BY-NC-ND 4.0 International license .

working in for-profit child care centers, even when controlling for personal sociodemographic characteristics. Child care professionals with asthma, diabetes, or obesity were more likely to have access to health insurance regardless of age or other sociodemographic characteristics, perhaps explainable by previous findings showing that individuals with medical insurance being more likely to use basic clinical services and therefore more likely to receive a primary care diagnosis and treatment. ${ }^{58}$

\section{Strengths and Limitations}

The major strength of our study is that it is a large national sample weighted to representativeness, allowing robust estimates of U.S. child care professionals' physical and mental health status and enough statistical power to explore subgroup conditions. The greatest methodological limitation is the sole reliance on self-reported information without medical or psychiatric examination to verify the reporting. Also, findings were obtained during the early months of the COVID-19 pandemic (May-June 2020), and the mental health impacts of the COVID-19 pandemic may have changed over time.

\section{Conclusions}

Given the impacts of the pandemic on this essential workforce, efforts should be directed toward developing effective and scalable interventions for improving their physical and mental health and addressing stressors that may undermine their wellbeing, such as long hours, low wages, and high job demands that are associated with child care professional stress, burnout and turnover. ${ }^{6,8}$ Our findings emphasize the need to further examine the health behaviors of child care 
medRxiv preprint doi: https://doi.org/10.1101/2022.03.01.22271717; this version posted March 2, 2022. The copyright holder for this preprint (which was not certified by peer review) is the author/funder, who has granted medRxiv a license to display the preprint in perpetuity.

It is made available under a CC-BY-NC-ND 4.0 International license.

professionals, via mixed-methods research, to understand what health initiatives might improve their overall wellbeing. 
medRxiv preprint doi: https://doi.org/10.1101/2022.03.01.22271717; this version posted March 2, 2022. The copyright holder for this preprint (which was not certified by peer review) is the author/funder, who has granted medRxiv a license to display the preprint in perpetuity.

\section{Contributors' Statement Page}

Mr. Elharake designed the study, conducted the literature search, contributed to data interpretation, and drafted the initial manuscript. Ms. Shafiq designed the study, analyzed the data, contributed to data interpretation, and drafted the initial manuscript. Dr. Cobanoglu analyzed the data, contributed to data interpretation, and contributed to critical revision of the manuscript. Dr. Malik designed the study, analyzed the data, contributed to data interpretation, and contributed to revision of the manuscript. Prof. Humphries, Prof. Murray, Dr. Patel, Mr. Wilkinson, Prof. Yildirim, Ms. Diaz, Ms. Rojas, Ms. Kuperwajs Cohen, Mr. Lee, and Prof. Reyes contributed to data interpretation and contributed to critical revision of the manuscript. Ms. Klotz led data acquisition and development of the online survey tool, contributed to data interpretation, and contributed to critical revision of the manuscript. Prof. Omer designed the study, contributed to the analytic approach, contributed to data interpretation, and contributed to critical revision of the manuscript. Prof. Gilliam is the senior author who conceptualized the study, designed the study, conducted the literature search, was involved in aspects of data collection and analysis, and contributed to critical revision of the manuscript. All authors approved the final manuscript as submitted and agree to be accountable for all aspects of the work.

All authors are members of the Yale Children and Adults Research in Early Education Study (Yale CARES) team.

\section{Acknowledgements}

This study was supported by The Andrew \& Julie Klingenstein Family Fund, Esther A. \& Joseph Klingenstein Fund, Heising-Simons Foundation, W.K. Kellogg Foundation, Foundation for 
medRxiv preprint doi: https://doi.org/10.1101/2022.03.01.22271717; this version posted March 2, 2022. The copyright holder for this preprint (which was not certified by peer review) is the author/funder, who has granted medRxiv a license to display the preprint in perpetuity. It is made available under a CC-BY-NC-ND 4.0 International license.

Child Development, Early Educator Investment Collaborative, Scholastic Inc, Yale Institute for Global Health, and Tobin Center for Economic Policy at Yale University. Invaluable assistance with obtaining child care provider contact information was provided by the National Workforce Registry Alliance (and its network of state child care workforce registries), Child Care Aware of America, and National Association for the Education of Young Children. Drs. Amalia Londoño Tobón and Adrián Cerezo Caballero provided Spanish translations and back translations of the survey measures and recruitment information. Alicia Alonso, Catherine Chang, Renee Dauerman, Stella FitzGerald, Harleen Kaur, Emma Knight, and Helen Mooney provided assistance in qualitative data categorization of respondent comments. 
medRxiv preprint doi: https://doi.org/10.1101/2022.03.01.22271717; this version posted March 2, 2022. The copyright holder for this preprint (which was not certified by peer review) is the author/funder, who has granted medRxiv a license to display the preprint in perpetuity. It is made available under a CC-BY-NC-ND 4.0 International license.

\section{References}

1. U.S. Bureau of Labor Statistics. Childcare Workers. U.S. Bureau of Labor Statistics. Personal Care and Service Web site. https://www.bls.gov/ooh/personal-care-andservice/childcare-workers.htm. Published 2020. Accessed January, 2022.

2. Datta AR, Milesi C, Srivastava S, Zapata-Gietl C. Home-Based Early Care and Education Providers in 2012 and 2019: Counts and Characteristics. Chartbook. National Survey of Early Care \& Education. OPRE Report 2021-85. Administration for Children \& Families. 2021.

3. Center for the Study of Child Care Employment. The Early Childhood Workforce Index - 2018. https://cscce.berkeley.edu/topic/earlychildhood-workforce-index/2018/.

Published 2018. Accessed January, 2022.

4. Chang D. Connecting The Dots: Improving Child Care Workers' Conditions Leads To Better Health, Economic Stability, And Greater Equity. https://www.healthaffairs.org/do/10.1377/forefront.20201019.28108/full/. Published 2020. Accessed January, 2022.

5. Vogtman J. Undervalued: A brief history of women's care work and child care policy in the United States. National Women's Law Center. 2017.

6. Cumming T, Wong S. Towards a holistic conceptualisation of early childhood educators' work-related well-being. Contemporary Issues in Early Childhood. 2019;20(3):265-281.

7. OECD. TALIS Providing Quality Early Childhood Education and Care Results from the Starting Strong Survey 2018. OECD Publishing; 2019. 
medRxiv preprint doi: https://doi.org/10.1101/2022.03.01.22271717; this version posted March 2, 2022. The copyright holder for this preprint (which was not certified by peer review) is the author/funder, who has granted medRxiv a license to display the preprint in perpetuity. It is made available under a CC-BY-NC-ND 4.0 International license.

8. Jeon H-J, Diamond L, McCartney C, Kwon K-A. Early Childhood Special Education Teachers’ Job Burnout and Psychological Stress. Early Education and Development. 2021:1-19.

9. Kwon K-A, Horm DM, Amirault C. Early Childhood Teachers' Well-Being: What We Know and Why We Should Care. ZERO TO THREE. 2021;41(3):35-44.

10. Haberman M. Teacher burnout in black and white. The new educator. 2005;1(3):153-175.

11. Murray J. In a time of COVID-19 and beyond, the world needs early childhood educators. In. Vol 28: Taylor \& Francis; 2020:299-302.

12. Swigonski NL, James B, Wynns W, Casavan K. Physical, mental, and financial stress impacts of COVID-19 on early childhood educators. Early Childhood Education Journal. 2021;49(5):799-806.

13. Schuchat A, Covid C, Team R. Public health response to the initiation and spread of pandemic COVID-19 in the United States, February 24-April 21, 2020. Morbidity and mortality weekly Report. 2020;69(18):551.

14. BLS Beta Labs. BLS Data Viewer. https://beta.bls.gov/dataViewer/view/timeseries/CES6562440010. Published 2021. Accessed January, 2022.

15. Career Explorer. The job market for childcare workers in the United States. Education \& Childcare Web site. https://www.careerexplorer.com/careers/childcare-worker/jobmarket/. Published 2016. Accessed January, 2022.

16. U.S. Census Bureau. Child Care. Families and Living Arrangements Web site. https://www.census.gov/topics/families/child-care.html. Published 2021. Accessed January, 2022. 
medRxiv preprint doi: https://doi.org/10.1101/2022.03.01.22271717; this version posted March 2, 2022. The copyright holder for this preprint (which was not certified by peer review) is the author/funder, who has granted medRxiv a license to display the preprint in perpetuity. It is made available under a CC-BY-NC-ND 4.0 International license.

17. Esposito S, Principi N. School closure during the coronavirus disease 2019 (COVID-19) pandemic: an effective intervention at the global level? JAMA pediatrics. 2020;174(10):921-922.

18. Otten JJ, Bradford VA, Stover B, et al. The culture of health in early care and education: workers' wages, health, and job characteristics. Health Affairs. 2019;38(5):709-720.

19. Sharma S, Dortch KS, Byrd-Williams C, et al. Nutrition-related knowledge, attitudes, and dietary behaviors among head start teachers in Texas: a cross-sectional study. Journal of the Academy of Nutrition and Dietetics. 2013;113(4):558-562.

20. Tovar A, Vaughn AE, Grummon A, et al. Family child care home providers as role models for children: cause for concern? Preventive medicine reports. 2017;5:308-313.

21. Linnan L, Arandia G, Bateman LA, Vaughn A, Smith N, Ward D. The health and working conditions of women employed in child care. International journal of environmental research and public health. 2017;14(3):283.

22. Aikens N, Tarullo L, Hulsey L, Ross C, West J, Xue Y. A Year in Head Start: Children, Families and Programs. ACF-ORPRE Report. Administration for Children \& Families. 2010.

23. Whitebook M, King E, Philipp G, Sakai L. Teachers' voices: Work environment conditions that impact teacher practice and program quality. 2017.

24. Whitaker RC, Becker BD, Herman AN, Gooze RA. The Physical and Mental Health of Head Start Staff: The Pennsylvania Head Start Staff Wellness Survey, 2012 Posted on November 15, 2013 by. 
medRxiv preprint doi: https://doi.org/10.1101/2022.03.01.22271717; this version posted March 2, 2022. The copyright holder for this preprint (which was not certified by peer review) is the author/funder, who has granted medRxiv a license to display the preprint in perpetuity. It is made available under a CC-BY-NC-ND 4.0 International license.

25. Whitaker RC, Dearth-Wesley T, Gooze RA. Workplace stress and the quality of teacherchildren relationships in Head Start. Early Childhood Research Quarterly. 2015;30:5769.

26. Statista. Percent of women in the U.S. who were diagnosed with diabetes in selected periods between 1988 and 2018. https://www.statista.com/statistics/666206/femalediabetes-prevalence-us/. Published 2021. Accessed January, 2022.

27. Fryar CD, Carroll MD, Afful J. Prevalence of overweight, obesity, and severe obesity among adults aged 20 and over: United States, 1960-1962 through 2017-2018. NCHS Health E-Stats. 2020.

28. National Institute of Mental Health. Major Depression. https://www.nimh.nih.gov/health/statistics/major-depression. Published 2019. Accessed January, 2022.

29. Ettman CK, Abdalla SM, Cohen GH, Sampson L, Vivier PM, Galea S. Prevalence of depression symptoms in US adults before and during the COVID-19 pandemic. JAMA network open. 2020;3(9):e2019686-e2019686.

30. Rosenberg M, Luetke M, Hensel D, Kianersi S, Fu T-c, Herbenick D. Depression and loneliness during April 2020 COVID-19 restrictions in the United States, and their associations with frequency of social and sexual connections. Social psychiatry and psychiatric epidemiology. 2021:1-12.

31. Ettman CK, Cohen GH, Abdalla SM, et al. Persistent depressive symptoms during COVID-19: a national, population-representative, longitudinal study of US adults. The Lancet Regional Health-Americas. 2022;5:100091. 
medRxiv preprint doi: https://doi.org/10.1101/2022.03.01.22271717; this version posted March 2, 2022. The copyright holder for this preprint (which was not certified by peer review) is the author/funder, who has granted medRxiv a license to display the preprint in perpetuity. It is made available under a CC-BY-NC-ND 4.0 International license.

32. Park AL, Velez CV, Kannan K, Chorpita BF. Stress, functioning, and coping during the COVID-19 pandemic: Results from an online convenience sample. The Behavior Therapist. 2020;43(6):210-216.

33. Smith S, Lawrence SM. Early care and education teacher well-being: Associations with children's experience, outcomes, and workplace conditions: A research-to-policy brief. 2019.

34. Herman KC, Hickmon-Rosa Je, Reinke WM. Empirically derived profiles of teacher stress, burnout, self-efficacy, and coping and associated student outcomes. Journal of Positive Behavior Interventions. 2018;20(2):90-100.

35. Kwon K-A, Jeon S, Jeon L, Castle S. The role of teachers' depressive symptoms in classroom quality and child developmental outcomes in Early Head Start programs. Learning and Individual Differences. 2019;74:101748.

36. Faulkner M, Gerstenblatt P, Lee A, Vallejo V, Travis D. Childcare providers: Work stress and personal well-being. Journal of Early Childhood Research. 2016;14(3):280-293.

37. Gratz RR, Claffey A. Adult health in child care: health status, behaviors, and concerns of teachers, directors, and family child care providers. Early Childhood Research Quarterly. 1996;11(2):243-267.

38. Gilliam WS, Malik AA, Shafiq M, et al. COVID-19 transmission in US child care programs. Pediatrics. $2021 ; 147(1)$.

39. Centers for Disease Control and Prevention. People with Certain Medical Conditions. COVID-19 Web site. https://www.cdc.gov/coronavirus/2019-ncov/need-extraprecautions/people-with-medical-conditions.html. Published 2022. Accessed February, 2022. 
medRxiv preprint doi: https://doi.org/10.1101/2022.03.01.22271717; this version posted March 2, 2022. The copyright holder for this preprint (which was not certified by peer review) is the author/funder, who has granted medRxiv a license to display the preprint in perpetuity. It is made available under a CC-BY-NC-ND 4.0 International license.

40. Cosco TD, Prina M, Stubbs B, Wu Y-T. Reliability and validity of the Center for Epidemiologic Studies Depression Scale in a population-based cohort of middle-aged US adults. Journal of nursing measurement. 2017;25(3):476-485.

41. Andresen EM, Malmgren JA, Carter WB, Patrick DL. Screening for depression in well older adults: Evaluation of a short form of the CES-D. American journal of preventive medicine. 1994;10(2):77-84.

42. Zhang W, O’Brien N, Forrest JI, et al. Validating a shortened depression scale (10 item CES-D) among HIV-positive people in British Columbia, Canada. PloS one. 2012;7(7):e40793.

43. Baik SH, Fox RS, Mills SD, et al. Reliability and validity of the Perceived Stress Scale10 in Hispanic Americans with English or Spanish language preference. Journal of health psychology. 2019;24(5):628-639.

44. Cohen S, Kamarck T, Mermelstein R. A global measure of perceived stress. Journal of health and social behavior. 1983:385-396.

45. NH Department of Administrative Services. Perceived Stress Scale. https://das.nh.gov/wellness/docs/percieved\%20stress\%20scale.pdf. Published 2020. Accessed January, 2022.

46. U.S. Census Bureau. Data Profiles. American Community Survey Web site. https://www.census.gov/acs/www/data/data-tables-and-tools/data-profiles/2019/. Published 2019. Accessed January, 2022.

47. United Health Foundation. Asthma - Women. Public Health Impact Web site. https://www.americashealthrankings.org/explore/health-of-women-andchildren/measure/asthma_women/state/ALL. Published 2019. Accessed January, 2022. 
medRxiv preprint doi: https://doi.org/10.1101/2022.03.01.22271717; this version posted March 2, 2022. The copyright holder for this preprint (which was not certified by peer review) is the author/funder, who has granted medRxiv a license to display the preprint in perpetuity. It is made available under a CC-BY-NC-ND 4.0 International license.

48. Louisias M, Phipatanakul W. Managing asthma in low-income, underrepresented minority, and other disadvantaged pediatric populations: closing the gap. Current allergy and asthma reports. 2017;17(10):1-7.

49. Pacheco CM, Ciaccio CE, Nazir N, et al. Homes of low-income minority families with asthmatic children have increased condition issues. Paper presented at: Allergy and asthma proceedings 2014 .

50. Bryant-Stephens T. Asthma disparities in urban environments. Journal of Allergy and Clinical Immunology. 2009;123(6):1199-1206.

51. Gilden R, Friedmann E, Spanier A, Hennigan C. Indoor air quality monitoring in Baltimore City, MD head start centers. International Journal of Environmental Science and Technology. 2021:1-8.

52. Ferng S-F, Li-Wen L. Indoor air quality assessment of daycare facilities with carbon dioxide, temperature, and humidity as indicators. Journal of Environmental Health. 2002;65(4):14.

53. Laquatra J, Maxwell L, Pierce M. Indoor air pollutants: limited-resource households and child care facilities. Journal of Environmental Health. 2005;67(7):39-43.

54. Carreiro-Martins P, Papoila AL, Caires I, et al. Effect of indoor air quality of day care centers in children with different predisposition for asthma. Pediatric Allergy and Immunology. 2016;27(3):299-306.

55. Centers for Disease Control and Prevention. Risk of severe illness from COVID-19. People with Moderate to Severe Asthma Web site. https://www.cdc.gov/coronavirus/2019-ncov/need-extra- 
medRxiv preprint doi: https://doi.org/10.1101/2022.03.01.22271717; this version posted March 2, 2022. The copyright holder for this preprint (which was not certified by peer review) is the author/funder, who has granted medRxiv a license to display the preprint in perpetuity. It is made available under a CC-BY-NC-ND 4.0 International license.

precautions/asthma.html\#: :text=People\%20with\%20moderate\%2Dto,steps\%20to\%20pr otect\%20yourself. Published 2021. Accessed February, 2022.

56. Centers for Disease Control and Prevention. Women and Heart Disease. About Heart Disease Web site. https://www.cdc.gov/heartdisease/women.htm. Published 2017. Accessed January, 2022.

57. Centers for Disease Control and Prevention. National diabetes statistics report, 2020. Atlanta, GA: Centers for Disease Control and Prevention, US Department of Health and Human Services. 2020:12-15.

58. Office of Disease Prevention and Health Promotion. Access to Health Services. The Healthy People 2020. Social Determinants of Health Web site.

https://www.healthypeople.gov/2020/topics-objectives/topic/social-determinantshealth/interventions-resources/access-to-health. Published 2020. Accessed January, 2022. 
medRxiv preprint doi: https://doi.org/10.1101/2022.03.01.22271717; this version posted March 2, 2022. The copyright holder for this preprint (which was not certified by peer review) is the author/funder, who has granted medRxiv a license to display the preprint in perpetuity.

Table 1: Sample Demographics and Prevalence of Physical Health Conditions by Sociodemographic Characteristics

\begin{tabular}{|c|c|c|c|c|c|}
\hline \multirow[b]{2}{*}{ Characteristic } & \multirow[b]{2}{*}{$\begin{array}{l}\text { Total } \\
\text { N (\%) }\end{array}$} & \multicolumn{4}{|c|}{ Physical Health Conditions } \\
\hline & & $\begin{array}{c}\text { Asthma } \\
\text { N (\%) }\end{array}$ & $\begin{array}{c}\text { Heart Disease } \\
\text { N }(\%) \\
\end{array}$ & $\begin{array}{c}\text { Diabetes } \\
\text { N (\%) }\end{array}$ & $\begin{array}{c}\text { Obesity } \\
\text { N (\%) }\end{array}$ \\
\hline Total & 81682 & $11717(14.3)$ & $3971(4.9)$ & $5317(6.5)$ & $16207(19.8)$ \\
\hline Age (Mean [std]) & $42.1(14.1)$ & $40.9(14.1)$ & $50.3(13.8)$ & $51.3(12.8)$ & $44.0(13.3)$ \\
\hline \multicolumn{6}{|l|}{ Race } \\
\hline White & $52164(63.8)$ & $7413(14.2)$ & $2520(4.8)$ & $2946(5.6)$ & $10905(20.9)$ \\
\hline American Indian/Alaska Native & $1582(1.9)$ & $298(18.8)$ & $91(5.8)$ & $178(11.2)$ & $330(20.9)$ \\
\hline Asian & $2949(3.6)$ & $325(11.0)$ & $121(4.1)$ & $195(6.6)$ & $195(6.6)$ \\
\hline Black/African American & $11837(14.5)$ & $1787(15.1)$ & $674(5.7)$ & $1209(10.2)$ & $2587(21.9)$ \\
\hline Multiracial & $2944(3.6)$ & $638(21.7)$ & $179(6.1)$ & $130(4.4)$ & $703(23.9)$ \\
\hline Native Hawaiian/Pacific Islander & $491(0.6)$ & $67(13.6)$ & $21(4.3)$ & $53(10.9)$ & $77(15.7)$ \\
\hline Prefer to not answer & $9731(11.9)$ & $1189(12.2)$ & $364(3.7)$ & $606(6.2)$ & $1410(14.5)$ \\
\hline \multicolumn{6}{|l|}{ Hispanic } \\
\hline No & $61806(75.7)$ & $9099(14.7)$ & $3207(5.2)$ & $4043(6.5)$ & $13121(21.2)$ \\
\hline Yes & $17753(21.7)$ & $2362(13.3)$ & $676(3.8)$ & $1112(6.3)$ & $2723(15.3)$ \\
\hline Prefer to not answer & $2139(2.6)$ & $255(11.9)$ & $88(4.1)$ & $163(7.6)$ & $363(17.0)$ \\
\hline \multicolumn{6}{|l|}{ Gender } \\
\hline Female & $78725(96.4)$ & $11358(14.4)$ & $3789(4.8)$ & $5106(6.5)$ & $15780(20.0)$ \\
\hline Male & $2033(2.5)$ & $231(11.4)$ & $139(6.8)$ & $149(7.3)$ & $267(13.1)$ \\
\hline Non-Binary & $225(0.3)$ & $51(22.8)$ & $14(6.3)$ & $11(4.8)$ & $51(22.7)$ \\
\hline Prefer to not answer & $715(0.9)$ & $76(10.6)$ & $29(4.1)$ & $52(7.3)$ & $109(15.2)$ \\
\hline \multicolumn{6}{|l|}{ Insurance } \\
\hline No & $8808(10.8)$ & $1012(11.5)$ & $327(3.7)$ & $424(4.8)$ & $1551(17.6)$ \\
\hline Yes & $72890(89.2)$ & $10705(14.7)$ & $3644(5.0)$ & $4893(6.7)$ & $14656(20.1)$ \\
\hline \multicolumn{6}{|l|}{ Program Type } \\
\hline \multicolumn{6}{|l|}{ Center-based } \\
\hline For-profit center & $19976(24.5)$ & $2861(14.3)$ & $1050(5.3)$ & $1222(6.1)$ & $4133(20.7)$ \\
\hline School-based & $10604(13.0)$ & $1529(14.4)$ & $450(4.2)$ & $465(4.4)$ & $1729(16.3)$ \\
\hline Head Start / Early Head Start & $8506(10.4)$ & $1309(15.4)$ & $370(4.4)$ & $637(7.5)$ & $1992(23.4)$ \\
\hline Drop-in center & $1596(2.0)$ & $220(13.8)$ & $49(3.1)$ & $69(4.3)$ & $210(13.1)$ \\
\hline Not-for-profit agency center & $15875(19.4)$ & $2336(14.7)$ & $802(5.1)$ & $1076(6.8)$ & $3588(22.6)$ \\
\hline Other center-based & $5949(7.3)$ & 945 (15.9) & $267(4.5)$ & $352(5.9)$ & $1073(18.0)$ \\
\hline Home-based / Family Child Care & $18078(22.1)$ & $2348(13.0)$ & $946(5.2)$ & $1435(7.9)$ & $3309(18.3)$ \\
\hline Nanny / In-Home Child Care & $1115(1.4)$ & $169(15.2)$ & $37(3.3)$ & $61(5.4)$ & $174(15.6)$ \\
\hline
\end{tabular}

Legend: The total column represents numbers and percentages of sociodemographic characteristics that make up the total sample. Diabetes, Heart Disease, Asthma, and Obesity columns show the numbers and percentages of the prevalence of the disease in that sociodemographic group (i.e., how many participants in a certain group reported having the disease). Due to sample waiting, frequencies may not add exactly to totals. 
medRxiv preprint doi: https://doi.org/10.1101/2022.03.01.22271717; this version posted March 2, 2022. The copyright holder for this preprint (which was not certified by peer review) is the author/funder, who has granted medRxiv a license to display the preprint in perpetuity.

It is made available under a CC-BY-NC-ND 4.0 International license.

Table 2: Logistic Regression of Physical Health Conditions and Sociodemographic

Characteristics

\begin{tabular}{|c|c|c|c|c|}
\hline Characteristic & $\begin{array}{c}\text { Asthma } \\
\text { OR }(95 \% \text { CI })\end{array}$ & $\begin{array}{l}\text { Heart Disease } \\
\text { OR }(95 \% \text { CI })\end{array}$ & $\begin{array}{c}\text { Diabetes } \\
\text { OR }(95 \% \text { CI })\end{array}$ & $\begin{array}{c}\text { Obesity } \\
\text { OR }(95 \% \text { CI })\end{array}$ \\
\hline Age & $0.99(0.99$ to 0.99$)$ & $1.04(1.04$ to 1.05$)$ & $1.05(1.05$ to 1.06$)$ & 1.01 (1.01 to 1.01$)$ \\
\hline \multicolumn{5}{|l|}{ Race } \\
\hline White & \multicolumn{4}{|c|}{ Reference } \\
\hline American Indian/Alaska Native & $1.44(1.23$ to 1.69$)$ & 1.42 (1.11 to 1.82$)$ & 2.34 (1.96 to 2.80$)$ & $1.11(0.95$ to 1.29$)$ \\
\hline Asian & $0.74(0.64$ to 0.84$)$ & $0.89(0.72$ to 1.11$)$ & 1.34 (1.11 to 1.62$)$ & $0.27(0.22$ to 0.31$)$ \\
\hline Black/African American & $1.09(1.02$ to 1.16$)$ & $1.14(1.03$ to 1.26$)$ & $1.86(1.71$ to 2.03$)$ & 1.01 (0.96 to 1.07$)$ \\
\hline Multiracial & $1.62(1.47$ to 1.79$)$ & $1.74(1.46$ to 2.08$)$ & $1.07(0.87$ to 1.31$)$ & 1.30 (1.18 to 1.43$)$ \\
\hline Native Hawaiian/Pacific Islander & $1.00(0.73$ to 1.37$)$ & $0.88(0.53$ to 1.45$)$ & $1.88(1.34$ to 2.64$)$ & $0.76(0.58$ to 0.99$)$ \\
\hline Prefer to not answer & $0.91(0.83$ to 0.99$)$ & $0.95(0.81$ to 1.11$)$ & $1.09(0.96$ to 1.23$)$ & $0.78(0.72$ to 0.85$)$ \\
\hline \multicolumn{5}{|l|}{ Hispanic } \\
\hline No & \multicolumn{4}{|c|}{ Reference } \\
\hline Yes & $0.90(0.85$ to 0.96$)$ & $0.95(0.85$ to 1.06$)$ & 1.34 (1.22 to 1.47$)$ & $0.75(0.71$ to 0.80$)$ \\
\hline Prefer to not answer & $0.90(0.76$ to 1.07$)$ & $0.82(0.61$ to 1.12$)$ & $1.23(0.98$ to 1.54$)$ & 0.93 (0.80 to 1.08$)$ \\
\hline \multicolumn{5}{|l|}{ Gender } \\
\hline Female & \multicolumn{4}{|c|}{ Reference } \\
\hline Male & $0.74(0.63$ to 0.88$)$ & $1.49(1.22$ to 1.80$)$ & $1.18(0.96$ to 1.44$)$ & $0.62(0.53$ to 0.73$)$ \\
\hline Non-Binary & $1.58(1.11$ to 2.25$)$ & $1.97(1.01$ to 3.84$)$ & $1.06(0.45$ to 2.48$)$ & $1.32(0.90$ to 1.93$)$ \\
\hline Prefer to not answer & $0.80(0.55$ to 1.17$)$ & $0.93(0.53$ to 1.65$)$ & $0.99(0.66$ to 1.50$)$ & $0.82(0.63$ to 1.07$)$ \\
\hline \multicolumn{5}{|l|}{ Insurance } \\
\hline Yes & \multicolumn{4}{|c|}{ Reference } \\
\hline No & $0.74(0.68$ to 0.80$)$ & 0.89 (0.77 to 1.02$)$ & $0.81(0.72$ to 0.92$)$ & $0.94(0.88$ to 1.00$)$ \\
\hline \multicolumn{5}{|l|}{ Program Type } \\
\hline For-profit center & \multicolumn{4}{|c|}{ Reference } \\
\hline Home-based & 0.94 (0.88 to 1.01$)$ & $0.83(0.74$ to 0.92$)$ & $0.99(0.89$ to 1.10$)$ & $0.85(0.80$ to 0.91$)$ \\
\hline Nanny/home-visiting & $1.02(0.84$ to 1.25$)$ & $0.89(0.58$ to 1.36$)$ & $1.27(0.91$ to 1.77$)$ & $0.82(0.67$ to 1.00$)$ \\
\hline Not for-profit center & $1.05(0.98$ to 1.12$)$ & $0.87(0.78$ to 0.97$)$ & $1.01(0.91$ to 1.11$)$ & $1.10(1.03$ to 1.17$)$ \\
\hline School-based & $0.99(0.91$ to 1.08$)$ & $0.90(0.78$ to 1.04$)$ & $0.78(0.69$ to 0.88$)$ & $0.81(0.75$ to 0.87$)$ \\
\hline Head Start / Early Head Start & $1.08(0.99$ to 1.17$)$ & $0.89(0.77$ to 1.02$)$ & $1.21(1.08$ to 1.35$)$ & $1.28(1.19$ to 1.37$)$ \\
\hline Drop-in center & $0.92(0.78$ to 1.09$)$ & $0.86(0.59$ to 1.24$)$ & 0.95 (0.69 to 1.30$)$ & $0.69(0.57$ to 0.84$)$ \\
\hline Other center-based & $1.14(1.03$ to 1.26$)$ & $0.91(0.77$ to 1.06$)$ & $1.00(0.87$ to 1.16$)$ & $0.89(0.81$ to 0.98$)$ \\
\hline
\end{tabular}


Table 3: Prevalence of Mental Health Outcomes by Sociodemographic Characteristics

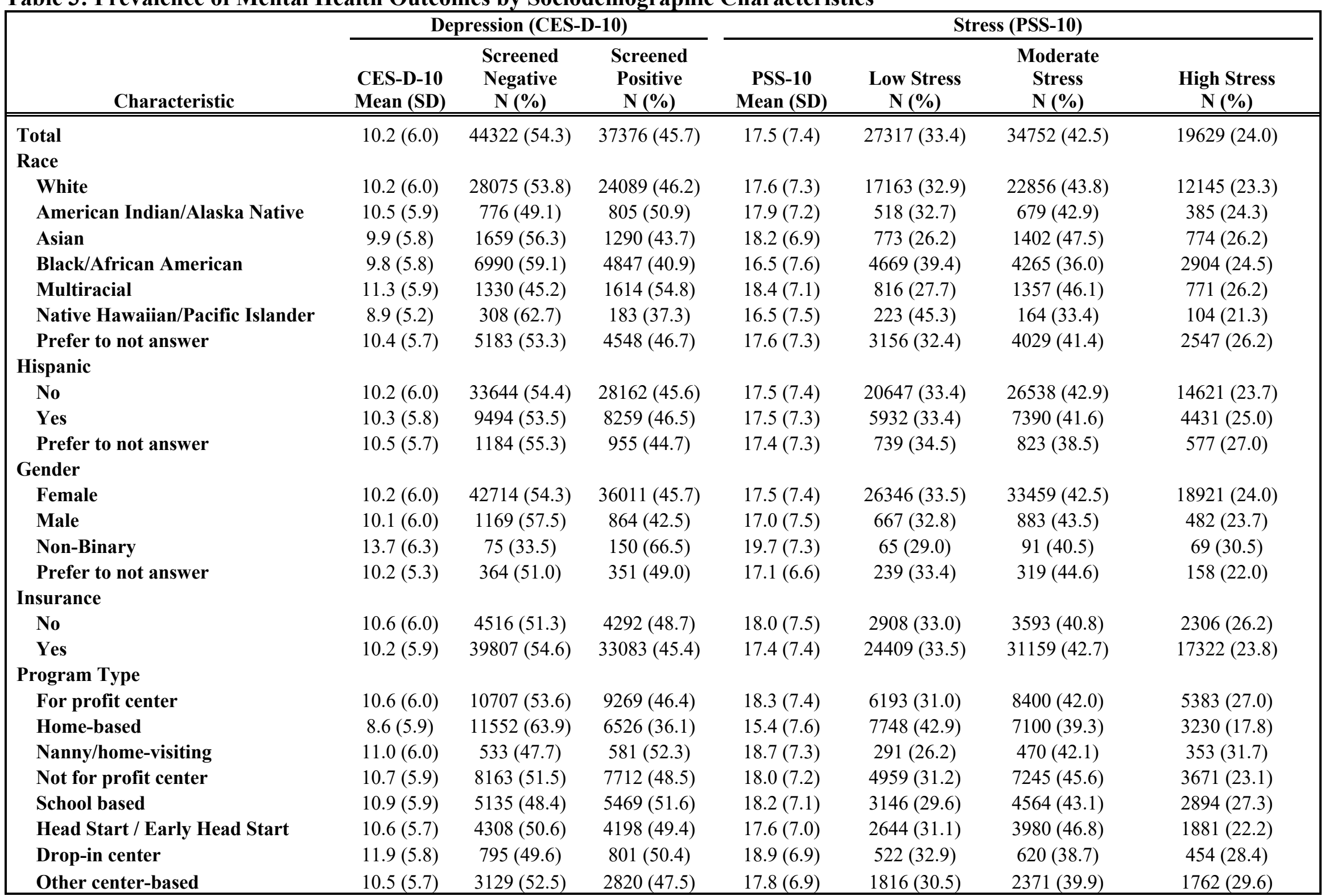


medRxiv preprint doi: https://doi.org/10.1101/2022.03.01.22271717; this version posted March 2, 2022. The copyright holder for this preprint (which was not certified by peer review) is the author/funder, who has granted medRxiv a license to display the preprint in perpetuity. It is made available under a CC-BY-NC-ND 4.0 International license.

Table 4: Linear Regression of CES-D-10, PSS-10, and Sociodemographic Characteristics

\begin{tabular}{|c|c|c|c|c|}
\hline \multirow{2}{*}{ Characteristic } & \multicolumn{2}{|c|}{ Depressive Symptoms (CES-D 10) } & \multicolumn{2}{|c|}{ Stress (PSS-10) } \\
\hline & $\beta(95 \%$ CI $)$ & Std. Error & $\beta(95 \%$ CI $)$ & Std. Error \\
\hline Age & $-0.11(-0.16$ to -0.05$)$ & 0.03 & $-0.07(-0.11$ to -0.03$)$ & 0.02 \\
\hline \multicolumn{5}{|l|}{ Race } \\
\hline White & \multicolumn{4}{|c|}{ Reference } \\
\hline American Indian/Alaska Native & $0.28(-1.60$ to 2.15$)$ & 0.90 & $0.14(-1.53$ to 1.82$)$ & 0.81 \\
\hline Asian & $0.53(-2.52$ to 3.57$)$ & 1.45 & $-0.39(-2.34$ to 1.55$)$ & 0.93 \\
\hline Black/African American & $-0.83(-2.17$ to 0.51$)$ & 0.64 & $-0.26(-1.18$ to 0.66$)$ & 0.44 \\
\hline $\begin{array}{l}\text { Multiracial } \\
\text { Native Hawaiian/Pacific }\end{array}$ & $0.11(-1.91$ to 2.13$)$ & 0.97 & $0.58(-1.29$ to 2.46$)$ & 0.90 \\
\hline Islander & $-0.60(-5.21$ to 4.01$)$ & 2.21 & $-1.09(-4.59$ to 2.41$)$ & 1.68 \\
\hline Prefer to not answer & $0.16(-1.83$ to 2.16$)$ & 0.95 & $0.28(-1.07$ to 1.63$)$ & 0.65 \\
\hline \multicolumn{5}{|l|}{ Hispanic } \\
\hline No & \multicolumn{4}{|c|}{ Reference } \\
\hline Yes & $-0.46(-1.67$ to 0.75$)$ & 0.58 & $-0.33(-1.50$ to 0.84$)$ & 0.56 \\
\hline Prefer to not answer & $-0.16(-2.46$ to 2.13$)$ & 1.10 & $0.08(-2.62$ to 2.79$)$ & 1.29 \\
\hline \multicolumn{5}{|l|}{ Gender } \\
\hline Female & \multicolumn{4}{|c|}{ Reference } \\
\hline Male & $-0.95(-3.52$ to 1.61$)$ & 1.23 & $-0.45(-2.29$ to 1.38$)$ & 0.88 \\
\hline Non-Binary & $0.97(-5.53$ to 7.47$)$ & 3.11 & $2.61(0.26$ to 4.95$)$ & 1.14 \\
\hline Prefer to not answer & $-0.42(-6.37$ to 5.53$)$ & 2.84 & $-0.27(-5.00$ to 4.47$)$ & 2.26 \\
\hline \multicolumn{5}{|l|}{ Insurance } \\
\hline Yes & \multicolumn{4}{|c|}{ Reference } \\
\hline No & $0.26(-1.49$ to 2.01$)$ & 0.83 & $0.27(-1.09$ to 1.63$)$ & 0.65 \\
\hline \multicolumn{5}{|l|}{ Program Type } \\
\hline For profit center & \multicolumn{4}{|c|}{ Reference } \\
\hline Home-based & $-2.30(-3.89$ to -0.72$)$ & 0.76 & $-1.54(-2.45$ to -0.63$)$ & 0.43 \\
\hline Nanny/home-visiting & $-0.49(-3.70$ to 2.73$)$ & 1.54 & $-0.20(-3.03$ to 2.63$)$ & 1.35 \\
\hline Not for profit center & $-0.02(-1.18$ to 1.13$)$ & 0.55 & $0.30(-0.47$ to 1.07$)$ & 0.37 \\
\hline School based & $-0.40(-2.10$ to 1.30$)$ & 0.81 & $0.11(-0.87$ to 1.09$)$ & 0.47 \\
\hline Head Start / Early Head Start & $-0.73(-2.77$ to 1.30$)$ & 0.97 & $-0.07(-1.24$ to 1.10$)$ & 0.56 \\
\hline Drop-in center & $-0.27(-4.06$ to 3.52$)$ & 1.81 & $0.73(-2.15$ to 3.61$)$ & 1.38 \\
\hline Other center-based & $-0.68(-2.58$ to 1.22$)$ & 0.91 & $-0.13(-1.59$ to 1.33$)$ & 0.70 \\
\hline
\end{tabular}


medRxiv preprint doi: https://doi.org/10.1101/2022.03.01.22271717; this version posted March 2, 2022. The copyright holder for this preprint (which was not certified by peer review) is the author/funder, who has granted medRxiv a license to display the preprint in perpetuity.

It is made available under a CC-BY-NC-ND 4.0 International license.

\section{Supplementary Online Content}

eMethods. Missing Data Analysis and Treatment

eTable 1. Prevalence of the Remaining Six Physical Health Outcomes by Sociodemographic Characteristics

eTable 2. Number of Chronic Diseases and Health Conditions by Sociodemographic Characteristics 
medRxiv preprint doi: https://doi.org/10.1101/2022.03.01.22271717; this version posted March 2, 2022. The copyright holder for this preprint (which was not certified by peer review) is the author/funder, who has granted medRxiv a license to display the preprint in perpetuity.

\section{eMethods}

\section{Missing Data Analysis and Treatment}

Missing data analysis included visual examination of missing data patterns and descriptive measures of missing values in the data. The chronic diseases and health conditions had $9.7 \%$ missing values, while CES-D-10 and PSS10 scores had $36.1 \%$ and $37.3 \%$ missing, respectively. Missingness in covariates ranged between $0.5 \%$ and $16 \%$. Little's Missing Completely at Random (MCAR) test was used to examine the missing data mechanism, and results suggested that the data are not MCAR $\left(\chi^{2}(9)=1515.807, p<0.001\right) .{ }^{1}$ Multiple Imputation (MI) was used to address missingness. ${ }^{2}$ Variables used for imputation included race, ethnicity, gender, age, child care program type, and access to medical insurance, and all the outcome variables i.e., CES-D-10, PSS-10, diabetes, heart disease, asthma, and obesity. Weight is also incorporated to fit imputation models. To ensure the precision and replicability of point estimates, we imputed 20 datasets using the Fully Conditional Specification Imputation Method, ${ }^{3}$ with pooled results from 20 datasets are reported in this paper.

\section{References}

1. Little RJ. A test of missing completely at random for multivariate data with missing values. Journal of the American Statistical Association. 1988;83(404):1198-1202.

2. Sterne JA, White IR, Carlin JB, et al. Multiple imputation for missing data in epidemiological and clinical research: potential and pitfalls. Bmj. 2009;338.

3. Lee KJ, Carlin JB. Multiple imputation for missing data: fully conditional specification versus multivariate normal imputation. American Journal of Epidemiology. 2010;171(5):624-632. 
eTable 1: Prevalence of the Remaining Six Physical Health Outcomes by Sociodemographic Characteristics

\begin{tabular}{|c|c|c|c|c|c|c|c|}
\hline Characteristic & $\begin{array}{l}\text { Total } \\
\mathbf{N}(\%) \\
\end{array}$ & $\begin{array}{c}\text { Chronic } \\
\text { Lung } \\
\text { Disease } \\
\mathbf{N}(\%) \\
\end{array}$ & $\begin{array}{c}\text { Smoking } \\
\mathrm{N}(\%) \\
\end{array}$ & $\begin{array}{c}\text { Chronic/Sever } \\
\text { e Kidney } \\
\text { Disease } \\
\text { N (\%) } \\
\end{array}$ & $\begin{array}{c}\text { Liver } \\
\text { Disease } \\
\mathbf{N}(\%) \\
\end{array}$ & $\begin{array}{c}\text { Immune- } \\
\text { Weakening } \\
\text { Medication } \\
\mathbf{s} \\
\mathbf{N}(\%) \\
\end{array}$ & $\begin{array}{c}\text { Immune- } \\
\text { Compromising } \\
\text { Conditions } \\
\text { N (\%) } \\
\end{array}$ \\
\hline Total & 81682 & $814(1.0)$ & $3619(4.4)$ & $562(0.7)$ & $\begin{array}{c}545(0.7) \\
46.1\end{array}$ & $3851(4.7)$ & $1884(2.3)$ \\
\hline Age (Mean [std]) & $42.1(14.1)$ & $54.0(13.0)$ & $39.7(13.4)$ & $48.6(14.9)$ & $(13.4)$ & $47.4(13.1)$ & $40.5(14.0)$ \\
\hline \multicolumn{8}{|l|}{ Race } \\
\hline White & $52164(63.8)$ & $575(1.1)$ & $2510(4.8)$ & $375(0.7)$ & $348(0.7)$ & $2617(5.0)$ & $1369(2.6)$ \\
\hline American Indian/Alaska Native & $1582(1.9)$ & $33(2.1)$ & $110(7.0)$ & $26(1.6)$ & $31(2.0)$ & $74(4.7)$ & $41(2.6)$ \\
\hline Asian & $2949(3.6)$ & $12(0.4)$ & $43(1.4)$ & $10(0.3)$ & $12(0.4)$ & $67(2.3)$ & $17(0.6)$ \\
\hline Black/African American & $11837(14.5)$ & $108(0.9)$ & $484(4.1)$ & $82(0.7)$ & $55(0.5)$ & $559(4.7)$ & $192(1.6)$ \\
\hline $\begin{array}{l}\text { Multiracial } \\
\text { Native Hawaiian/Pacific }\end{array}$ & $2944(3.6)$ & $18(0.6)$ & $186(6.3)$ & $13(0.4)$ & $22(0.8)$ & $138(4.7)$ & $108(3.7)$ \\
\hline Islander & $491(0.6)$ & $12(2.4)$ & $26(5.3)$ & $2(0.3)$ & $3(0.5)$ & $24(4.9)$ & $17(3.4)$ \\
\hline Prefer to not answer & $9731(11.9)$ & $57(0.6)$ & $260(2.7)$ & $56(0.6)$ & $75(0.8)$ & $371(3.8)$ & $141(1.5)$ \\
\hline \multicolumn{8}{|l|}{ Hispanic } \\
\hline No & $61806(75.7)$ & $714(1.2)$ & $3081(5.0)$ & $450(0.7)$ & $381(0.6)$ & $3151(5.1)$ & $1573(2.5)$ \\
\hline Yes & $17753(21.7)$ & $69(0.4)$ & $466(2.6)$ & $104(0.6)$ & $144(0.8)$ & $613(3.5)$ & $271(1.5)$ \\
\hline Prefer to not answer & $2139(2.6)$ & $30(1.4)$ & $72(3.4)$ & $8(0.4)$ & $21(1.0)$ & $87(4.0)$ & $40(1.9)$ \\
\hline \multicolumn{8}{|l|}{ Gender } \\
\hline Female & $78725(96.4)$ & $786(1.0)$ & $3422(4.3)$ & $534(0.7)$ & $498(0.6)$ & $3759(4.8)$ & $1811(2.3)$ \\
\hline Male & $2033(2.5)$ & $12(0.6)$ & $135(6.6)$ & $19(0.9)$ & $29(1.4)$ & $41(2.0)$ & $38(1.9)$ \\
\hline Non-Binary & $225(0.3)$ & $5(2.1)$ & $38(16.7)$ & $8(3.4)$ & $0(0)$ & $22(9.7)$ & $27(12.0)$ \\
\hline Prefer to not answer & $715(0.9)$ & $12(1.7)$ & $25(3.4)$ & $2(0.2)$ & $3(0.5)$ & $29(4.0)$ & $9(1.3)$ \\
\hline \multicolumn{8}{|l|}{ Insurance } \\
\hline No & $8808(10.8)$ & $64(0.7)$ & $569(6.5)$ & $42(0.5)$ & $49(0.6)$ & $253(2.9)$ & $136(1.5)$ \\
\hline Yes & $72890(89.2)$ & $750(1.0)$ & $3050(4.2)$ & $520(0.7)$ & $496(0.7)$ & $3598(4.9)$ & $1749(2.4)$ \\
\hline \multicolumn{8}{|l|}{ Program Type } \\
\hline For-profit center & $19976(24.5)$ & $203(1.0)$ & $1112(5.6)$ & $146(0.7)$ & $119(0.6)$ & $946(4.7)$ & $521(2.6)$ \\
\hline Home-based & $18078(22.1)$ & $214(1.2)$ & $500(2.8)$ & $127(0.7)$ & $120(0.7)$ & $922(5.1)$ & $339(1.9)$ \\
\hline Nanny/home-visiting & $1115(1.4)$ & $23(2.1)$ & $49(4.4)$ & $9(0.8)$ & $5(0.5)$ & $56(5.0)$ & $48(4.3)$ \\
\hline
\end{tabular}




\begin{tabular}{lccccccc|} 
Not for-profit center & $15875(19.4)$ & $165(1.0)$ & $665(4.2)$ & $98(0.6)$ & $110(0.7)$ & $806(5.1)$ & $395(2.5)$ \\
School-based & $10604(13.0)$ & $78(0.7)$ & $359(3.4)$ & $65(0.6)$ & $82(0.8)$ & $457(4.3)$ & $247(2.3)$ \\
Head Start / Early Head Start & $8506(10.4)$ & $82(1.0)$ & $532(6.3)$ & $71(0.8)$ & $60(0.7)$ & $382(4.5)$ & $189(2.2)$ \\
Drop-in center & $1596(2.0)$ & $8(0.5)$ & $134(8.4)$ & $3(0.2)$ & $10(0.6)$ & $44(2.7)$ & $20(1.2)$ \\
Other center-based & $5949(7.3)$ & $40(0.7)$ & $268(4.5)$ & $44(0.7)$ & $39(0.7)$ & $239(4.0)$ & $124(2.1)$ \\
\hline
\end{tabular}

Legend: The total column represents numbers and percentages of sociodemographic characteristics that make up the total sample. Disease columns show the numbers and

percentages of the prevalence of the disease in that sociodemographic group (i.e., how many participants in a certain group reported having the disease). 
medRxiv preprint doi: https://doi.org/10.1101/2022.03.01.22271717; this version posted March 2, 2022. The copyright holder for this preprint (which was not certified by peer review) is the author/funder, who has granted medRxiv a license to display the preprint in perpetuity.

eTable 2: Number of Chronic Diseases and Health Conditions by Sociodemographic Characteristics

\begin{tabular}{|c|c|c|c|c|}
\hline \multirow[b]{2}{*}{ Characteristic } & \multicolumn{4}{|c|}{ Number of Chronic Diseases of Health Conditions } \\
\hline & $\begin{array}{l}\text { None } \\
\text { N (\%) } \\
\end{array}$ & $\begin{array}{c}\text { One } \\
\mathrm{N}(\%) \\
\end{array}$ & $\begin{array}{c}\text { Two } \\
\text { N (\%) } \\
\end{array}$ & $\begin{array}{c}\text { Three of } \\
\text { More } \\
\mathbf{N}(\%) \\
\end{array}$ \\
\hline Total & $49099(60.1)$ & $21398(26.2)$ & $7962(9.7)$ & $3239(4.0)$ \\
\hline Age (Mean [std]) & $41.1(13.9)$ & $42.7(14.1)$ & $44.5(13.8)$ & $48.1(13.7)$ \\
\hline \multicolumn{5}{|l|}{ Race } \\
\hline White & 30874 (59.2) & 14009 (26.9) & $5174(9.9)$ & $2107(4.0)$ \\
\hline American Indian/Alaska Native & $863(54.6)$ & $421(26.6)$ & $181(11.4)$ & $117(7.4)$ \\
\hline Asian & $2221(75.3)$ & $538(18.3)$ & $138(4.7)$ & $51(1.7)$ \\
\hline Black/African American & $6718(56.8)$ & $3271(27.6)$ & $1319(11.1)$ & $530(4.5)$ \\
\hline Multiracial & $1561(53.0)$ & $832(28.3)$ & $406(13.8)$ & $146(4.9)$ \\
\hline Native Hawaiian/Pacific & & & & \\
\hline Islander & $305(62.1)$ & $113(23.1)$ & $48(9.7)$ & $25(5.1)$ \\
\hline Prefer to not answer & $6557(67.4)$ & $2214(22.8)$ & $697(7.2)$ & $263(2.7)$ \\
\hline \multicolumn{5}{|l|}{ Hispanic } \\
\hline No & 35969 (58.2) & $16739(27.1)$ & $6410(10.4)$ & $2588(4.3)$ \\
\hline Yes & $11738(66.1)$ & $4154(23.4)$ & $1392(7.8)$ & $468(2.6)$ \\
\hline Prefer to not answer & $1392(65.1)$ & $505(23.6)$ & $160(7.5)$ & $82(3.8)$ \\
\hline \multicolumn{5}{|l|}{ Gender } \\
\hline Female & $47227(60.0)$ & $20662(26.2)$ & $7709(9.8)$ & $3127(4.0)$ \\
\hline Male & $1300(64.0)$ & $498(24.5)$ & $169(8.3)$ & $65(3.2)$ \\
\hline Non-Binary & $88(39.2)$ & $80(35.6)$ & $33(14.9)$ & $23(10.3)$ \\
\hline Prefer to not answer & $484(67.7)$ & $157(21.9)$ & $51(7.1)$ & $23(3.3)$ \\
\hline \multicolumn{5}{|l|}{ Insurance } \\
\hline No & 5654 (64.2) & $2212(25.1)$ & $711(8.1)$ & $231(2.6)$ \\
\hline Yes & $43445(59.6)$ & $19186(26.3)$ & $7251(9.9)$ & $3008(4.1)$ \\
\hline \multicolumn{5}{|l|}{ Program Type } \\
\hline For-profit center & 11757 (58.9) & $5359(26.8)$ & $2008(10.1)$ & $852(4.3)$ \\
\hline Home-based & $11247(62.2)$ & $4438(24.5)$ & $1687(9.3)$ & $706(3.9)$ \\
\hline Nanny/home-visiting & $717(64.3)$ & $246(22.1)$ & $103(9.3)$ & $48(4.3)$ \\
\hline Not for-profit center & $9171(57.8)$ & $4369(27.5)$ & $1635(10.3)$ & $699(4.4)$ \\
\hline School-based & $6755(63.7)$ & $2692(25.4)$ & $844(8.0)$ & $313(3.0)$ \\
\hline Head Start / Early Head Start & $4783(56.2)$ & $2369(27.0)$ & $972(11.4)$ & $381(4.5)$ \\
\hline Drop-in center & $1053(66.0)$ & $374(26.2)$ & $126(7.9)$ & $43(2.7)$ \\
\hline Other center-based & $3617(60.8)$ & $1549(26.0)$ & $586(9.8)$ & $197(3.3)$ \\
\hline
\end{tabular}

